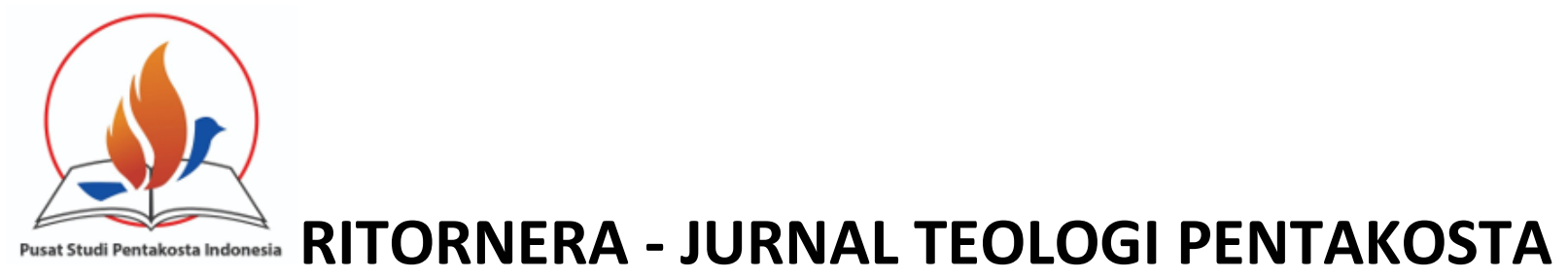

\title{
INDONESIA
}

Vol. 1, No. 2, August 2021

Available at: pspindonesia.org

\section{Tinjauan Teologis Konsep Hidup Berkelimpahan dalam \\ Perspektif Teologi Kemakmuran}

\author{
Sri Lina Betty Lamsihar Simorangkir ${ }^{1}$ \\ srilinasimorangkir67@gmail.com
}

Andreas Marhain Sumarno 2

andreassumarno65@gmail.com

\begin{abstract}
The Bible is the word of God which teaches the truth by understanding it through comprehensive study. In following Jesus, believers must return to the correct understanding of materiality and wealth so as not to be trapped. In this study, it was found that living in abundance in the teachings of prosperity theology does not indicate that God's children must be prosperous and abundant in material things. This study uses qualitative methods with exposition and exegesis approaches. Thus, it can be concluded that the theological review of the concept of abundant life in the perspective of prosperity theology. First, it brings the congregation to understand the nature of Abundant Life in prosperity theology by looking at the background and teachings of Prosperity Theology. Furthermore, understanding in a comprehensive manner that a Bible review of several verses that are used as the basis for Abundant Life as a Prosperity Theology Teaching becomes an apologist who brings a new paradigm. And the last Bible review of abundance in a biblical perspective and educating believers' attitudes about wealth according to the Bible.
\end{abstract}

Keywords: abundant life, Bible, material wealth, prosperity theology

\section{Abstrak}

Alkitab adalah firman Allah yang mengajarkan kebenaran dengan memahaminya melalui mempelajarinya secara konprihensif. Dalam mengikut Yesus, orang percaya harus kembali kepada pemahaman yang benar tentang materi dan kekayaan agar tidak terjebak. Dalam penelitian ini di dapatkan bahwa hidup berkelimpahan dalam ajaran teologi kemakmuran tidak menunjukkan bahwa anak Tuhan harus makmur dan berlimpah dalam materi. Penelitian ini menggunakan metode kualitatif dengan pendekatan eksposisi dan eksegesa. Demikian dapat disimpulkan bahwa 
tinjauan teologis konsep hidup berkelimpahan dalam perspektif teologi kemakmuran. Pertama membawa jemaat dapat mengerti hakikat Hidup berkelimpahan dalam teologi kemakmuran dengan melihat latar belakang berdiri dan Ajaran Teologi Kemakmuran. Selanjutnya memahami secara konfrernhensif bahwa tinjauan Alkitab tentang beberapa ayat yang dipergunakan sebagai dasar untuk Hidup Berkelimpahan Sebagai Ajaran Teologi Kemakmuran menjadi apologet yang membawa paradigma baru. Dan yang terakhir Tinjauan Alkitab tentang kelimpahan dalam perspektif Alkitab dan mengedukasi bagi Sikap orang percaya tentang kekayaan Menurut Alkitab.

Kata kunci: hidup berkelimpahan, Alkitab, kekayaan materi, teologi kemakmuran

\section{PENDAHULUAN}

Setiap yang percaya kepada Tuhan hidupnya penuh dengan kelimpahan dengan materi, sehat secara jasmani, tanpa sakit penyakit, dan tidak pernah gagal. Pernyataan-pernyataan ini merupakan propaganda yang dicetuskan oleh ajaran teologi kemakmuran. Pengajaran ini sekaligus menarik untuk diteliti apakah benar bahwa setiap orang Kristen harus berkelimpahan dan hidup sukses, tanpa diterpa sakit penyakit. Pengajaran 'hidup berkelimpahan' telah masuk di dalam gereja dan umat Tuhan. Pengajaran seperti ini telah menarik sebagian pengikut Yesus berhasrat untuk melimpah dengan materi. Anggapannya bahwa semua kekayaan di dunia ini adalah milik Allah maka anak-anak Allah berhak atasnya, bahkan harus mengklaim sebagai miliknya. ${ }^{1}$ Sebagian yang membingungkan bagi umat Tuhan yang sedang dalam penderitaan karena sakit dan kekurangan sebagai orang miskin yang seolah-olah hidup ditinggalkan Tuhan dan tidak beriman teguh atau juga dapat dikategorikan akibat dosa. Ada juga anggapan ada yang belum menerima pengajaran materialisme serta sebagai Kristen yang ajarannya dianggap dalam kekeliruan. ${ }^{2}$

Merebaknya pengajaran teologi kesuksesan bahwa hidup berkelimpahan menjadi identitas pengikut Kristus, menyebabkan munculnya dua kubu antara pro dan kontra. Kubu yang lain menyatakan bahwa hidup berkelimpahan secara rohani dan tidak harus paksakan mengejar materi.

\footnotetext{
${ }^{1}$ Sihol Christian Robirosa Simanuhuruk, Teologi Kemakmuran. Apakah: Orang Benar Harus Kaya? Miskin Itu Karena Dosa? (Malang: Gandum Mas, 2009).

${ }^{2}$ Jim Bakker, Teologi Kemakmuran Dan Kedatangan Tuhan. (Jakarta: Metanoia, 2005). 
Kubu lainnya menyatakan bahwa kekayaan dalam kelimpahan harus dikejar dan juga kekayaan secara rohani. ${ }^{3}$ Kubu-kubu yang berbeda-beda ini berada pada status sebagai umat Tuhan (jemaat) dan sebagai pendeta yang memberitakan firman Tuhan untuk mencintai dan mengejar uang dan kekayaan. Pengajaran ini telah menyuburkan sifat ketamakan yang pada kenyataannya mengarah kepada pemuasan kesenangan pendengaran seperti II Tim. 4:3. Bahaya yang muncul adalah menyangkal Penebus (II Petr.2:1-4) dan menjadi orang Kristen yang pemahamannya kabur tentang kewajiban sebagai pengikut Yesus dan memikul salibnya (Mat.16:24).

Semua umat Tuhan sangat penting memahami pengajaran yang benar dan murni bahkan juga tentang berkelimpahan. Tujuannya adalah iman yang benar (Roma 10:17), juga adanya penyesatan (Mat. 16:12; Kol.2:8). Yesus memperingatkan para murid agar waspada dengan pengajaran orang Farisi dan Saduki (Mat. 16:12). Timotius dalam pantauan Paulus menegaskan agar mengawasi ajarannya (1 Tim. 4:16), lalu penting menasehati mereka yang mengajarkan ‘ajaran lain’ di luar Injil Yesus Kristus (1Tim.1:3). Titus diperintahkan untuk memberitakan “ajaran sehat" (Tit.2:1).

Sebagai perbandingan yang penulis tunjukkan mengenai ajaran hidup berkelimpahan dihubungkan di saat sekarang pada masa pandemic covid-19 sejak awal tahun 2020 di seluruh dunia telah dinyatakan ada virus yang mematikan manusia serta berimbas pada ekonomi termasuk para pekerjanya. ${ }^{4}$ Putu menyatakan penghasilan pekerjaan secara finansial dan fisik yang terkena covid -19 menurun drastis sampai ke golongan ekonomi lemah. ${ }^{5}$ Dampak covid-19 yang nyata

\footnotetext{
${ }^{3}$ Simanuhuruk, Teologi Kemakmuran. Apakah: Orang Benar Harus Kaya? Miskin Itu Karena Dosa?

${ }^{4}$ Joseph Christ Santo and Yonatan Alex Arifianto, "Kajian Teologis 1 Petrus 5:7 Tentang Perlindungan Allah Terhadap Orang Percaya Di Tengah Pandemi Covid-19," Kharismata: Jurnal Teologi Pantekosta 4, no. 1 (2021): 1-15, https://www.e-journal.stajember.ac.id/index.php/kharismata/article/view/80/pdf.

${ }^{5}$ Putu Agung Nara Indra Prima Satya, ““'Covid- 19 Dan Potensi Konflik Sosial,” Jurnal Ilmiah Hubungan Internasional 0, no. 0 (2020): 39-45.
} 
kepada perekonomian dunia semakin berat. ${ }^{6}$ Ditambah lagi, korban terinfeksi covid-19 bukan sedikit, bahkan jutaan orang dan sampai masuk mengalami kematian dan diberbagai tempat mengalami kerugian besar terasa pada social, keamanan, serta keuangan. ${ }^{7}$ Maka dapat dinyatakan bahwa seluruh dunia mengalami dan menjadi perhatian dalam hal itu dimana tidak dapat lepas berdampak kepada kesahihan pemahaman hidup berkelimpahan menjadi nyata atau tidak. Yang terpapar virus covid 19 banyak berujung kepada kematian, bukan kesembuhan dan hidup serta keadaan ekonomi semakin terpuruk bukan berkelimpahan. Ada juga yang harus menggadai hartanya, sehingga berkurang dan bukan berkelimpahan. Yusep Mulyana menyatakan bahwa peta perdagangan dunia telah berubah secara mendadak akibatnya selain mandek berbagai bidang usaha juga kinerja global dipastikan terganggu. ${ }^{8}$ Pada saat ini telah masuk kepada situasi kesulitan, kekurangan, masalah penderitaan, kesemuanya secara global.

Tanpa menyalahi satu dengan lainnya dan mencari akar mula penyebabnya maka sangat perlu pembahasan ajaran yang benar dan murni sesuai Firman Tuhan yang dalam cara penafsiran yang benar. Dalam penafsiran yang dipergunakan ajaran kemakmuran secara eisegese dimana konsep yang diperoleh terlebih dahulu kemudian dicarikan ayat pendukung yang dapat mendukung pemahaman. ${ }^{9}$ Seolah-olah seperti dipaksakan ayat Firman Tuhan untuk mendukung ide pemahaman yang dianggap sudah benar. Tidak jarang menjadi firman, ${ }^{10}$ bukan sebagai firman Tuhan sesuai penafsiran yang tepat. Pendukung yang dipergunakan sebagai pemahaman hidup berkelimpahan seperti Yoh.10:10 'Aku datang supaya mempunyainya dalam kelimpahan', Roma 8:32, II Kor. 8:9;

\footnotetext{
${ }^{6}$ Chairul Baharudin, Ikhsan and Muhammad Abdi, and Nur, “Ancaman Krisis Ekonomi Global Dari Dampak Penyebaran Virus Corona (Covid-19)," AkMen Jurnal Ilmiah (2020).

${ }^{7}$ Debby Christ Mondolu and and Obet Nego, "Covid-19: Wabah Alkitabiah, Relevankah?," SCRIPTA: Jurnal Teologi dan Pelayanan Kontekstual 9, no. 1 (2020): 32-51.

${ }^{8}$ Yusep Mulyana, "Peranan Ekonomi Pembangunan Pasca Covid 19," PRISMAKOM Sekolah Tinggi Ilmu Ekonomi Yasa Anggana Garut 17, no. 1 (2020): 37-45.

${ }^{9}$ Simanuhuruk, Teologi Kemakmuran. Apakah: Orang Benar Harus Kaya? Miskin Itu Karena Dosa?

${ }^{10}$ Bakker, Teologi Kemakmuran Dan Kedatangan Tuhan.
} 
Roma 10:11; 3 Yoh.2; Filipi 4:19, semua ayat itu dianggap sebagai layaknya seorang percaya untuk hidup berkelimpahan.

Seperti gambaran singkat di atas, dalam penelitian ini dirancang memberikan wawasan untuk setiap orang memutuskan sendiri agar kembali kepada ajaran yang murni Firman Tuhan. Sebab itu diperlukan penyelidikan yang saksama tentang arti dan makna ayat-ayat Alkitab yang dipakai sebagai dasar pengajaran tentang berkelimpahan, sikap yang benar terhadap harta dan kekayaan itu sendiri. Hendaknya pemahaman yang benar sudah harus diketahui oleh gereja yaitu semua orang percaya juga para mahasiswa teologi serta para pendeta termasuk doktrin. Dalam hal ini maka perlu lebih dahulu melepaskan praduga yang telah dipegang untuk masuk pada prinsipprinsip dan cara menafsirkan Alkitab secara bertanggungjawab.

\section{METODE}

Dalam penelitian ini, penulis menggunakan metode kualitatif dengan pendekatan eksegesis dan eksposisi Alkitab. Kata eksegesa (exegomai - Yunani) berarti membawa ke luar atau mengangkat ke luar atau mengeluarkan makna. ${ }^{11}$ Sonny Zaluchu menyatakan bahwa eksegese adalah serangkaian prosedur yang dilakukan untuk mencari makna teks. Selanjutnya ia juga menunjukkan kata eksposisi berasal dari bahasa Latin ex (artinya keluar) dan posit/ponere (artinya meletakkan). Eksposisi adalah penyusunan hasil eksegesa secara berurutan, per kata atau per ayat. Atau per paragraph, yang disertai dengan aplikasi untuk kehidupan modern. ${ }^{12}$ Dengan menggunakan Alkitab sebagai sumber primer dan memakai tinjauan literatur jurnal dan buku-buku lain yang mendukung penyelesaiannya. Dari makna literal dan makna kontekstual, maka dapat disusun kajian yang dituangkan secara deskriptif.

\footnotetext{
${ }^{11}$ Dr. Sonny Eli Zaluchu M.Th, Biblical Theology, 2nd ed. (Semarang: Golden Gate, 2017), 22.
}

12 Ibid., 23. 


\section{HASIL DAN PEMBAHASAN}

\section{Pengertian Hidup Berkelimpahan dalam Teologi Kemakmuran}

Kata 'berkelimpahan' terambil dari kata dasar 'limpah' yang di dalam Kamus Besar Bahasa Indonesia memiliki arti, yaitu : Satu, Tumpah ke luar karena terlalu banyak atau penuh (tentang barang cair); Dua, Kelimpahan : tertumpah banyak, dikaruniai (diberi) banyak-banyak. ${ }^{13}$ Bila di awali dengan 'ber' pada 'berkelimpahan' maka artinya mempunyai sesuatu yang banyak-banyak. Hidup berkelimpahan memiliki hubungan erat dengan teologi kemakmuran sehingga hidup berkelimpahan itu menunjukkan kepada pemilikan material, kesehatan dan kesuksesan, dalam taraf hidup. Maka arti hidup berkelimpahan adalah hidup yang memiliki fasilitas dalam hal materi sebanyak-banyaknya dalam hal jumlah dan jenis, terlalu banyak. Lebih dari yang diperlukan ${ }^{14}$ sebenarnya yang penting adalah fungsi dari suatu barang, bukan banyaknya.

Penekanan pada pesan kemakmuran diharuskan agar orang Kristen berharap menerima kekayaan, kesehatan, kesuksesan, kebahagiaan, dan kepuasan diri di dunia ini. Para pengajar kemakmuran menyebarkan ajaran bahwa Tuhan lah yang menginginkan supaya anda menjadi makmur. ${ }^{15}$ Semua itu dipropagandakan lebih mengarah kepada materi sampai banyak pendeta tergoda 'memiliki segala-galanya' disaat hidup. ${ }^{16}$ Kemakmuran popular di mulai dari Amerika pada pelayanan para pengkhotbah di TV evangelist dari denominasi Pentakosta (neo Pentacostal) maupun Kharismatik. Para televangelist telah mengumandangkan dengan ajarannya tentang Tuhan yang tidak hanya memberkati secara spiritual tetapi juga dalam kesehatan dan kekayaan. Semua itu

\footnotetext{
13 Amran Y S Chaniago, “Kamus Lengkap Bahasa Indonesia,” Bandung: Pustaka Setia (2002): 800.

${ }^{14}$ Op.Cit. Sihol Christian Robirosa Simanihuruk, 53.

${ }^{15}$ John Avanzini., Untaian Nasehat Mengenai Kemakmuran (Semarang: Literatur Gereja JKI-INJIL KERAJAAN, 1997), 21.

${ }^{16}$ Bakker, Teologi Kemakmuran Dan Kedatangan Tuhan. 
diperoleh jika telah menabur dalam bentuk memberi perpuluhan, ${ }^{17}$ sebab Allah membuktikan kasih-Nya kepada umat-Nya. Semua berkat kesehatan dan kekayaan karena pengorbanan Kristus maka seluruh umat Tuhan harus hidup dalam kelimpahan termasuk kesehatan dan kekayaan. Para televangelist yang terkenal ini diantaranya pendeta Joel Osteen, Morris Cerullo, yang mengajarkan iman dengan kata positif: Robert Schuller, Norman Vincent Peale; visualisasi: Kenneth Copeland, Yonggi Cho; investasi materi berbentuk persembahan: Oral Roberts.

Pencetus munculnya pengajaran hidup berkelimpahan diantaranya seperti di Amerika Serikat beberapa gereja Pentakostal. Mereka mengklaim bahwa Allah menginginkan supaya orang percaya sukses khususnya dalam keuangan sebagai bukti diperkenankan Allah, wujud penyertaan Allah, dan tanda dikasihi Allah. ${ }^{18}$ Dasar yang dipergunakan dari Ulangan 8:18 'Dialah yang memberikan kepadamu kekuatan untuk memperoleh kekayaan, dengan maksud meneguhkan perjanjian". Penganut ajaran ini yang menginginkan kemakmuran jasmaniah bertujuan untuk mendanai pekabaran Injil ke seluruh dunia.

\section{Latar Belakang Berdiri danAjaran Teologi Kemakmuran}

Ada yang menyatakan dalam penelusurannya bahwa Teologi Kemakmuran dalam gerakan Gnostik abad ke-2 M. pelopornya disebut E.W. Kenyon (1867-1948) dari Inggris. Ia seorang pengkhotbah, pendidik, dan penulis handal yang dari gereja Metodist kemudian hijrah ke gereja Baptis, dan terakhir hijrah ke Pentakosta. Peneliti yang lain menyebutkan bahwa Kenyon dipengaruhi oleh filosofi Gerakan Zaman Baru, ada juga disebutkan karena pengaruh Pentakosta

\footnotetext{
${ }^{17}$ Avanzini., Untaian Nasehat Mengenai Kemakmuran.

${ }^{18}$ Hengki Wijaya, "Evaluasi Kritis Terhadap Teologi Sukses” (2012). 
aliran Faith Prosperity Theology. Slogannya yang dipakai yaitu 'apa yang saya akui, itu yang saya miliki' (what I confess, I possess) dengan penekanan pada iman untuk mendapatkan janji Allah. ${ }^{19}$

Doktrin kemakmuran atau yang disebut sebagai Teologi Kemakmuran : Prosperity Theology atau Prosperity Gospel, yang disebut juga sebagai Teologi Sukses. Penebusan oleh Yesus Kristus dilakukan Allah untuk memberkati dengan kesuksesan dan kesehatan. Ada unsur mencari keuntungan dari penderitaan Yesus sampai mati di kayu salib yang akan memberkati umat Tuhan dengan disahkannya pengumpulan uang sebanyaknya di dalam gereja. Pandangan ini seolah-olah mengkaitkan tujuan penebusan Allah melalui Yesus hanya pada materi atau kekayaan. Gerakan ini mengalami kejayaan saat Amerika mengalami perkembangan dalam industri dengan materi yang limpah ruah pada abad XIX paska Perang Dunia II.

Pemahaman yang dikembangkan oleh Norman Vincent Peale dipergunakan Robert Schuller yaitu kombinasi psikologi dan agama yang disebut "religio-psychriatric clinic". Ini adalah cara seorang psikiater di gerejanya dalam konseling kepada jemaat dimana ketika ditemukan penyebab dasar masalah saat konseling, maka para pelayan menerapkan penanganannya dengan pengobatan agama: doa, iman, dan kasih. $^{20}$ Para Teolog kemakmuran melakukan pelayanan dengan mempergunakan karunia Roh, kesembuhan ilahi, serta menari di dalam Roh. Sementara itu, seseorang harus mengetahui bahwa Allah berkehendak makmur di dalam hidupnya, maka ia mengalami kemakmuran. Syaratnya adalah ketaatan, ketika tidak taat maka tidak ada kemakmuran. teologi kemakmuran dapat terjadi sebab yakin bahwa Allah dapat melakukan mujizat kesembuhan. Mujizat terjadi saat para pelayan harus berdoa untuk memperoleh karunia kesembuhan itu. Doktrin

\footnotetext{
${ }^{19}$ Stephen G. Walangare, "Teologi Kemakmuran,” Kompasiana.Com.

${ }^{20}$ Wijaya, "Evaluasi Kritis Terhadap Teologi Sukses." 
Teologi Kemakmuran berkenaan dengan doktrin Allah Bapa (God the Father), ada konsep iman, dosa, keselamatan, kehidupan Kristen dan karya gereja.

Di dalam Yoh.10:10 dituliskan "Pencuri datang hanya untuk mencuri dan membunuh dan membinasakan; Aku datang, supaya mereka mempunyai hidup, dan mempunyainya dalam segala

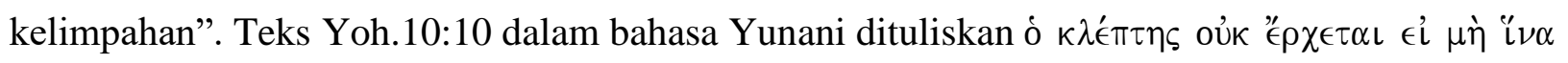

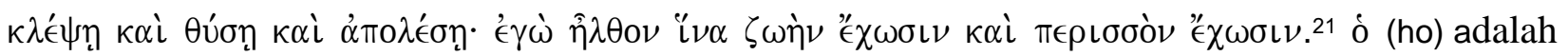
kata sandang definit nominatif maskulin tunggal; $\kappa \lambda \lambda^{\prime} \pi \tau \eta \varsigma$ (kleptes) adalah kata benda maskulin tunggal umum artinya pencuri; oủk (ouk) adalah kata keterangan yang artinya tidak; " $€ \chi \chi \epsilon \tau$ ' (erchetai) leksikalnya $\varepsilon \rho \chi о \mu \alpha \iota$ adalah kata kerja indikatif present medial orang ke 3 tunggal artinya datang; $\epsilon$ (ei)adalah kata sambung subordinasi artinya jika; $\mu \eta(\mathrm{me})$ adalah partikel artinya tidak;

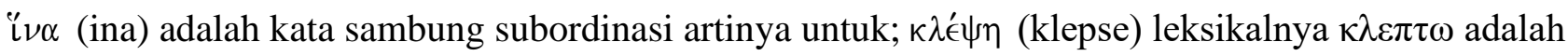

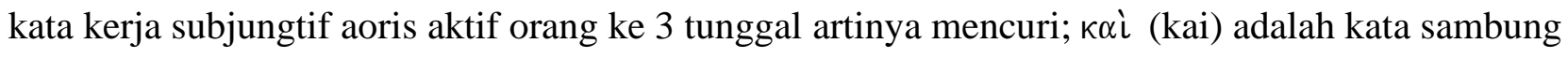
koordinasi artinya dan; $\theta$ v́ø̣ (thuse) leksikalnya $\theta v \omega$ (thuo) adalah kata kerja subjungtif aoris aktif orang ke 3 tunggal artinya menyembelih; к $\alpha$ (kai) adalah kata sambung koordinasi artinya dan;

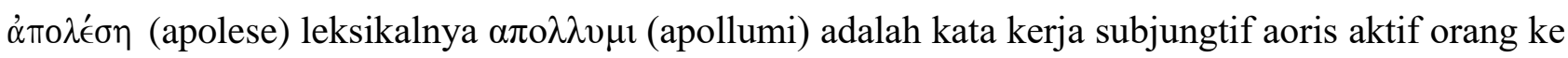
3 tunggal artinya menghancurkan; 'ُ $\gamma \omega$ (ego) adalah kata ganti personal nominatif tunggal artinya Aku; $\hat{\eta} \lambda \theta o \nu$ (Elton) leksikalnya $\varepsilon \rho \chi o \mu \alpha \iota$ adalah kata kerja indikatif aoris aktif orang pertama

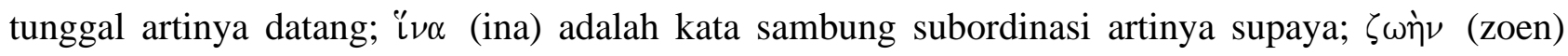

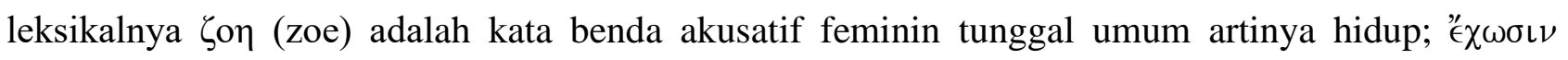
(echosin) leksikalnya $\varepsilon \chi \omega$ (echo) adalah kata kerja subjungtif presen aktif orang ke 3 jamak artinya

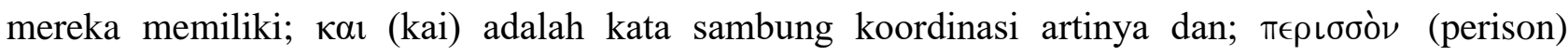

${ }^{21}$ Bible Work 7,0 0,12g, n.d.

Copyright(C2021; Ritornera - Jurnal Teologi Pentakosta Indonesia |69 


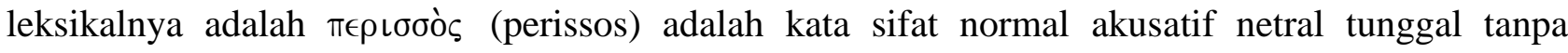
tingkatan artinya melimpah; ${ }^{\prime} \chi \omega \sigma \iota \nu$ (echosin) leksikalnya $\varepsilon \chi \omega$ (echo) adalah kata kerja subjungtif presen aktif orang ke 3 jamak artinya mereka memiliki. ${ }^{22}$

Dari eksegesis di atas peneliti memberi arti "Pencuri tidak datang jika tidak untuk mencuri dan menyembelih dan menghancurkan, Aku datang agar mereka memiliki hidup dan memiliki kelimpahan". Dua bagian kontras antara pencuri yang mencuri dan menyembelih dan menghancurkan dengan Tuhan Yesus sebagai gembala maka dari eksegesis didapat perkataan hidup

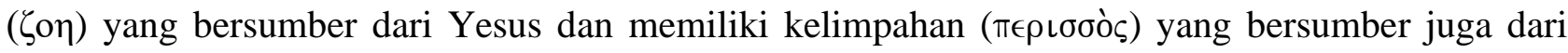
Yesus. Tidak ada indikasi makna kelimpahan ditujukan pada kekayaan materi. Bila mempergunakan prinsip prinsip penafsiran maka Christian Robirosa menyatakan bahwa pengertian ini dapat menjadi supaya mereka terus memiliki hidup dan terus mempunyai dengan kelimpahan. ${ }^{23}$

\section{Landasan untuk Hidup Berkelimpahan Sebagai Ajaran Teologi Kemakmuran}

\section{Arti berkelimpahan}

Dalam Yohanes 10:10 'Aku datang agar mereka mempunyai hidup dan mempunyainya dalam segala kelimpahan'. Ayat ini sebagai rujukan doktrin kemakmuran serta berkelimpahan dalam kualitas dan kuantitas. "Allah adalah Allah yang mahabesar, kaya dengan rahmat dan penuh berkat dan manusia beriman akan mengalami kehidupan yang berlimpah dan kehidupan yang penuh

${ }^{22}$ BibleWorks 7,0 0,12g, n.d.

${ }^{23}$ Simanuhuruk, Teologi Kemakmuran. Apakah: Orang Benar Harus Kaya? Miskin Itu Karena Dosa?, 73. Copyright $\bigcirc 2021$; Ritornera - Jurnal Teologi Pentakosta Indonesia |70 
berkat, kaya dan berlimpah materi’. Banyak orang Kristen terjebak dan tidak menyadari jika itu, ${ }^{24}$ dalam pemahaman yang keliru sekalipun mempergunakan Firman Tuhan. Pemahaman yang dipakai bukan dalam penafsiran yang benar dan bertanggungjawab tetapi hanya secara literal. Kata 'hidup' dipakai dengan bahasa Yunani adalah 'zoe' yang menunjukkan 'kehidupan roh dan jiwa'. Zoe biasa dianggap konsep kehidupan yang lebih mulia dan lebih tinggi. Jadi Makna yang sebenar dari Yoh 10:10 yang Yesus inginkan adalah hidup kelimpahan dalam roh. ${ }^{25}$ Harus melihat pada ayat 9 bahwa Yesus adalah pintu kepada selamat untuk memperoleh hidup yang kekal yang dapat mempunyai semua yang diperlukan yaitu membebaskan manusia dari dosa, kesalahan, dan hukuman. ${ }^{26}$

Artinya bukan berkaitan dengan materi seperti uang, rumah, emas dan perak. Mark 12:29-31 menegaskan pentingnya mengasihi Tuhan, dengan segenap hati dan dengan segenap jiwa dan dengan segenap akal budi dan dengan segenap kekuatan. Juga mengasihi sesama manusia seperti diri sendiri. Ini sebagai hubungan persekutuan dengan Tuhan Yesus dan sesama manusia karena mengalami keselamatan. Bila kembali kepada makna kelimpahan, adalah kelimpahan hidup yang belum pasti secara materi. ${ }^{27}$ Yesus adalah pintu dimana Yesus dalam Yoh. 5:26 menyatakan Bapa memiliki hidup dimana hidup yang diberikan kepada Anak yaitu Yesus juga memiliki hidup dalam diriNya sendiri. Pintu ini yang menuju hadirat Allah. ${ }^{28}$ Dalam 1 Yoh.1:2, Yohanes mendefinisikan hidup kekal berkenaan dengan Kristus yang diperoleh melalui iman dan dalam persekutuan. Yesus yang Pemimpin kepada hidup (Kisah 3:15) yang kekal yang satu saat akan mengubah tubuh jasmani (II Kor.5:4) pada saat Yesus datang kembali yang kedua kali. Maka, pengertian hidup

\footnotetext{
${ }^{24}$ Bakker, Teologi Kemakmuran Dan Kedatangan Tuhan.

25 Ibid.

${ }^{26}$ Alkitab Hidup Berkelimpahan Life Application Study Bible (Malang: Gandum Mas, 2016), 1722.

${ }^{27}$ Simanuhuruk, Teologi Kemakmuran. Apakah: Orang Benar Harus Kaya? Miskin Itu Karena Dosa?

${ }^{28}$ Leon Morris, Teologi Perjanjian Baru, Pertama. (Malang: Gandum Mas, 1996). 
berkelimpahan adalah hidup yang beriman kepada Kristus sebagai pusat hidup kekal. Tidak ada jalan lain untuk menuju hidup yang mau tidak mau berkaitan dengan Kristus. ${ }^{29}$ Sifat 'kekal' menghubungkan dengan dunia yang akan datang seperti perkataan Yesus kepada Marta,'Akulah kebangkitan dan hidup; barangsiapa percaya kepada-Ku, ia akan hidup walau telah mati ...' ada aspek eskatologis yang kuat. Jadi, bukan menunjuk kepada kelimpahan secara materi atau harta melainkan pada kelimpahan rohani yang sudah dalam kepastian untuk hidup yang kekal.

Dalam Roma 8:32 'Ia mengaruniakan segala sesuatu’. Kata 'segala sesuatu' telah dipergunakan dalam teologi kemakmuran untuk menyatakan sebagai hidup yang berkelimpahan secara materi, harta dan kemewahan. Paulus menulis surat Roma untuk jemaat yang saat itu sementara sedang dalam penderitaan (tahun 58 AD) di bawah pemerintahan Kaisar Nero. Tuduhan dan siksaan yang hebat diarahkan kepada orang-orang Kristen bahkan sebelumnya oleh Kaisar Klaudius. Paulus sedang menulis tentang Allah yang memelihara di saat penderitaan dan ketidaknyamanan dari pemimpin. Maka Paulus bukan memberi janji tentang segala harta tetapi menyatakan pemeliharaan Allah dalam menghadapi segala penderitaan yang bertubi-tubi untuk tetap beriman kepada Yesus Kristus (ay. 38-39) yang tidak terpisahkan oleh apapun juga. Kata 'segala sesuatu' diperlukan demi keselamatan maka 'segala sesuatu' itu merupakan kuasa atas alam semesta dan apa saja yang diperlukan demi keselamatan, ${ }^{30}$ baik pada saat mengalami penderitaan juga sampai saat dinyatakannya keselamatan itu.

Dalam 2 Korintus 8:9 '...supaya kamu menjadi kaya oleh karena kemiskinan-Nya'. Pengajaran kontemporer dari ayat ini menunjukkan bahwa tujuan kedatangan Tuhan menginginkan supaya orang percaya menjadi kaya secara materi. Pada ay.2 kaya dalam kemurahan, ay 7 kaya

\footnotetext{
${ }^{29}$ Ibid.

${ }^{30}$ Van Den End, “Tafsiran Alkitab Surat Roma,” Jakarta: BPK Gunung Mulia (1995): 400-402. 
dalam segala sesuatu mencakup dalam iman, dalam perkataan, dalam pengetahuan, dalam kesungguhan membantu, dan dalam kasih terhadap Paulus. Jadi, maksudnya adalah kaya dalam rohani dan bukan kaya secara materi. Orang-orang Kristen bisa miskin secara harta, tetapi kaya dalam iman (Yak. 2:5) yang mewarisi Kerajaan Surga. Yesus menjadi miskin materi dengan cara berkorban dengan memberi kekayaan kekal bagi orang percaya. ${ }^{31}$ Jadi, tidak tepat bila karya Kristus menjadikan orang Kristen menjadi kaya materi saja. Dalam 3 Yohanes 2 ‘... semoga engkau baik-baik dan sehat-sehat saja ...' kata 'euodoo' (Yunani) artinya 'mempunyai jalan yang baik, dipimpin pada jalan yang baik'. Pengertiannya dimana doa Yohanes bagi orang percaya saat menempuh jalan keselamatan dalam kehendak Allah dan kebenaran-Nya dengan meminta kecukupan dalam pemenuhan kebutuhan hidup namun Allah mungkin mengizinkan anak-Nya mengalami masa-masa kekurangan. Dengan itu didorong untuk mengembangkan iman, ketabahan rohani dan pelayanan kepada Tuhan (II Kor. 4:7-12; I Petr.1:6-7). Menjadi kesaksian hidup kepada orang lain di mana hadirnya Tuhan pada tantangan hidup yang berat. Ada lagi gagasan yang lain, di mana kehadiran, pertolongan, berkat Allah dalam kehidupan jasmani berkaitan dengan kehidupan rohani. ${ }^{32}$ Seperti, harus mencari kehendak Allah, menaati Roh Kudus, mengasihi Firman Allah, bekerja keras dan lainnya. Maka, kata 'baik-baik' tidak mengarah kepada materi tetapi lebih dominan harus dinyatakan dalam cara rohani untuk berkat rohani dalam menghadapi kemungkinankemungkinan yang tidak terprediksi.

Dalam Filipi 4:19 frase 'menurut kekayaan dan kemuliaan-Nya' diterjemahkan 'menurut kekayaan kemuliaan-Nya’ berhubung ay.18 Paulus telah mendapat pemberian dari jemaat Filipi dan ia tidak dapat membalas pemberian itu. Ucapan Paulus bahwa Allah dapat membalaskan dengan

\footnotetext{
${ }^{31}$ Lembaga Alkitab Indonesia, ed., Alkitab Penuntun Hidup Berkelimpahan, keenam. (Malang: Gandum Mas, 2002), 1930.

${ }^{32}$ Indonesia, Alkitab Penuntun Hidup Berkelimpahan. Copyright(C2021; Ritornera - Jurnal Teologi Pentakosta Indonesia |73
} 
memenuhi segala keperluan menurut kekayaan Allah yang tidak habis-habisnya dalam kemuliaan yang dibagi melalui Yesus Kristus. ${ }^{33}$ Paulus mendapat perhatian pemberian, maka harapan Paulus hanya Allah yang akan memberikan balasan menurut kekayaan kemuliaan Yesus. Jadi, sulit menyatakan kalau ini tentang kelimpahan materi sekalipun bisa terjuwud secara materi.

\section{Tinjauan Alkitab tentang Teologi Kemakmuran.}

Alkitab menyatakan ajaran tentang Allah Tritunggal adalah suatu doktrin yang sangat penting dalam iman Kristen. Allah Bapa yang terhubung dengan manusia melalui Yesus Kristus bukan sekedar mengampuni dosa manusia tetapi memberi jaminan kepada kehidupan kekal (Yoh. $3: 16 ; 10: 10)$. Ketika orang percaya pada Yesus dan mau menerima-Nya secara pribadi sebagai Tuhan dan Juruselamatnya maka ia diangkat menjadi anak-anak Allah (Yoh. 1:12). Salah satu sifat Allah adalah Allah Mahakasih. Teologi Kemakmuran telah salah mengerti pada konsep ini yang selayaknya ditujukan bagi manusia yang telah rusak Gambar Allah untuk menerima manusia kembali melalui pengorbanan Yesus di kayu salib. Penyalahgunaan konsep tentang kasih hanya tertuju kepada bagian berkat yaitu materi, kesehatan dan sukses.

Jaminan hidup di dalam Tuhan Yesus Kristus nyata pada ajaran kekristenan bagi para pengikutnya agar selalu percaya dan tetap berharap kepada Tuhan di dalam segala lini kehidupan. Alkitab telah menjadi sumber petunjuk pada persoalan hidup manusia, juga mengenai jaminan pemeliharaan Tuhan yang diinginkan setiap manusia agar bebas dari kekuatiran dan kecemasan. ${ }^{34}$ Pada Perjanjian Lama dan Perjanjian Baru menjadi acuan mengenai konsep pemeliharaan Allah serta proteksi bagi umat Tuhan pada masa kesulitan yang menghebat sehingga umat Tuhan tetap

\footnotetext{
${ }^{33}$ Autrey Jarry, Surat Kiriman Penjara. (Malang: Gandum Mas, 1988), 64-65.

${ }^{34}$ S.J Darminta, Peziarahan Keluarga (Yoyakarta: Kanisius, 2006), 63. 
terpelihara. ${ }^{35}$ Sejak penciptaan, semuanya terpelihara dalam pemeliharaan Allah dan dunia ini sesuai tujuannya tetap dalam pimpinan-Nya. ${ }^{36}$ Jadi, mata iman umat Tuhan hendaknya bukan ditujukan hanya seterusnya kepada materi dan kekayaan saja.

Konsep pemeliharaan Allah dalam penderitaan telah dinyatakan secara alkitabiah dan bukan suatu doktrin saja namun pemeliharaan Allah diwujudkan kepada manusia yang sekalipun berdosa. ${ }^{37}$ Hadirnya penderitaan hidup dapat menghancurkan ekonomi, kesehatan dan juga kehidupan social serta tidak terlepas menghantam nilai-nilai religious dan spiritual. ${ }^{38}$ Lebih dalam lagi, siapapun dapat masuk ke dalam masalah-masalah yang bisa bertubi-tubi bahkan sampai masuk pada kematian sekalipun, itu adalah hak prerogratif Allah. Seperti pernyataan rasul Paulus yang menyatakan bahwa kematian itu merupakan keuntungan (Fil.1:21-22). Pemeliharaan Allah itu sudah dijamin dan diberi jalan keluar dari pencobaan yang dialami (1 Kor. 10:13) yang menyatakan sebagai kasih Allah kepada umat-Nya. Menjadi penting, bahwa Allah memelihara bukan hanya dalam melimpahkan secara materi namun menjadi perhatian bahwa Allah juga mengijinkan pencobaan dialami.

Melihat kepada latar belakang para tokoh-tokoh Teologi Kemakmuran ternyata mereka mempergunakan konsep yang keliru seperti cenderung pergunakan pemahaman psikologi tentang kekuatan pikiran. Ditambah dengan pemahaman teologi yang tidak murni pemahamannya. Kemungkinan pemahaman yang keliru berdasarkan penafsiran yang mengutip ayat firman Tuhan sesuai dengan keinginan sendiri, bukan pada konsep penafsiran yang benar secara hermeneutik

\footnotetext{
${ }^{35}$ Santo and Arifianto, "Kajian Teologis 1 Petrus 5:7 Tentang Perlindungan Allah Terhadap Orang Percaya Di Tengah Pandemi Covid-19."

${ }^{36}$ Harun Hadiwijono, Iman Kristen (Jakarta: BPK Gunung Mulia, 2007), 213.

${ }^{37}$ Santo and Arifianto, "Kajian Teologis 1 Petrus 5:7 Tentang Perlindungan Allah Terhadap Orang Percaya Di Tengah Pandemi Covid-19."

${ }^{38}$ David Alinurdin, “COVID-19 Dan Tumit Achilles Iman Kristen,” VERITAS Jurnal Teologi dan Pelayanan 19, no. 1 (2020): 1-9.
}

Copyright(C2021; Ritornera - Jurnal Teologi Pentakosta Indonesia |75 
(eisegese). Mengenai iman, Alkitab menyatakan bahwa iman timbul karena mendengar firman Tuhan (Roma 10:17) sebab kabar baik yaitu Injil menjadi suatu kekuatan yang menyelamatkan manusia (Roma 1:16-17). Berpikir positif bukanlah iman, sangat berseberangan. Manusia berkenan di hadapan Allah karena iman, "tanpa iman manusia tidak berkenan dihadapan Allah" (Ibrani 11:6). Sedangkan iman nyata di dalam pencobaan yang menjadi tantangan untuk teruji seperti kualitas emas iman Ayub (Ayub 23:10). 1 Petr. 1:6-7 membuktikan kemurnian iman yang jauh lebih tinggi nilainya dari emas yang fana. Harun mengungkapkan pada penghakiman Allah posisi manusia dapat dibenarkan karena mempunyai kebenaran Allah dalam iman kepada Yesus Kristus. ${ }^{39}$ Iman ini pula menjadi unsur penting yang ditujukan pada pengorbanan Yesus buat penebusan dosa manusia. ${ }^{40}$ Lebih dalam pernyataan Charles Stanley menunjukkan bahwa iman bukanlah suatu kekuatan yang digantungkan pada leher Allah untuk mau melakukan keinginan manusia, memaksa Allah bertindak, menjadikan seperti tombol yang siap melakukan permintaan, justru iman itu adalah mempercayai apa yang sudah Allah kerjakan sesuai janji-Nya. ${ }^{41}$

Ada beberapa makna berkat yang dapat menjadi acuan di dalam memaknai hidup berkelimpahan dalam pendekatan untuk hidup sehari-hari ${ }^{42}$, diantaranya pertama harta benda yang terbagi secara materi dan uang. Harta benda berguna untuk memfasilitasi kehidupan manusia, uang sebagai alat tukar dalam bertransaksi dan merupakan kebutuhan umum bagi manusia. Ungkapan

\footnotetext{
${ }^{39}$ Hadiwijono, Iman Kristen, 407.

${ }^{40}$ A Simanjuntak, Tafsiran Alkitab Masa Kini 3 Matius-Wahyu, 8th ed. (Jakarta: Yayasan Komunikasih Bina Kasih/OMF, 1994), 422.

${ }^{41}$ Charles Stanley, The Glorious Journal (Perjalanan Mulia) (Batam Center: Interaksara, 2000), 277.

${ }^{42}$ Finilon and I Ketut Enoh, "TINJAUAN TEOLOGIS TENTANG ARTI BERKAT DALAM KEHIDUPAN ORANG PERCAYA,” Jurnal Jaffray 10, no. 1 (2012): 148-173, https://ojs.sttjaffray.ac.id/JJV71/article/view/72/pdf_50.
} 
Jake Barnett menyatakan bahwa manusia memiliki hubungan dengan uang sekitar lima puluh persen. ${ }^{43}$ Hal ini dapat diartikan bahwa hidup manusia secara mental, pikiran, emosi telah berfokus pada uang. Orang menjadi jahat karena hatinya mencintai uang lebih dari nilai-nilai keselamatan (1 Tim. 6:10) dan ketika memiliki uang maka itu tidak jahat. Kekayaan yang tidak disalahgunakan bukan dosa, namun ketamakan akan uang yang diburu tanpa memakai rambu-rambu nilai-nilai iman membawa manusia pada ketamakan. ${ }^{44}$ Alkitab memberi tanggapan mengenai kekayaan sebagai penyembahan berhala (Kol.3:5) maka orang yang tamak dapat menjadikan kekayaannya sebagai berhala. Ini adalah kekeliruan dan telah nyata sebagai penyimpangan dari iman. Tuhan telah tersingkirkan oleh berkat. Kedua, dalam pelayanan Yesus selalu berada dalam perbuatan mujizat. Ada banyak penyakit, bermacam-macam mengalami kesembuhan bahkan sampai orang mati pun dibangkitkan. Dalam ulasan buku, Daniel Ronda menyatakan bahwa kesembuhan itu berada dalam kedaulatan Allah sebab hak sepenuh dalam otoritas-Nya, melewati proses seperti pengobatan, bahkan masuk dalam kondisi meninggal. ${ }^{45}$ Bagi gereja masa kini harus melakukan pelayanan yang membuktikan bahwa Tuhan itu ada dan hidup, berkuasa atas penyakit melalui pelayanan mendoakan orang sakit. ${ }^{46}$ Di sisi lain, perlu menyandingkan hidup berkelimpahan dalam kesehatan dengan para disabilitas. Penyandang disabilitas juga merindukan bukan hanya kemapanan dan kelimpahan materi, namun kelepasan sebagai disabilitas.

Konsep dosa pada Roma 3:23 "semua manusia telah berbuat dosa”, ayat 10 menyatakan manusia tidak ada yang benar, tidak berakal budi, dan tidak ada yang mencari Allah. Sementara doktrin Kemakmuran menyatakan dosa itu hanya pada perasaan yang menyudutkan diri sendiri.

\footnotetext{
43 Jake Barnett, Harta Dan Hikmat (Bandung: Kalam Hidup, 1983), 20.

${ }^{44}$ Finilon and Enoh, "TINJAUAN TEOLOGIS TENTANG ARTI BERKAT DALAM KEHIDUPAN ORANG PERCAYA."

${ }^{45}$ Daniel Ronda, "Ulasan Buku: Bagaimana Aku Dapat Meminta Allah Untuk Kesembuhan Fisik?: Panduan Alkitabiah,” Jurnal Jaffray 13, no. 1 (2015), https://ojs.sttjaffray.ac.id/JJV71/article/view/118.

46 Ibid. 
Seharusnya dengan perasaan yang diperburuk atau tertuduh akan membawa merasa pentingnya Yesus dalam mengampuni dosa dan melayakkan untuk diterima dan disambut menjadi milik Allah. Dalam sebuah renungan GKI Pengharapan menyatakan bahwa keberadaan manusia yang berdosa adalah sebagai manusia yang sudah tidak sesuai dengan standar Allah serta sama sekali tidak memiliki kemuliaan Allah. Yaitu tindakan pembunuhan, pemerkosaan, pencurian, perzinahan, perselisihan, kemarahan dan seperti ini telah menjadi gaya hidup orang yang kehilangan kemuliaan Allah. ${ }^{47}$ Jadi sebenarnya manusia bukan hanya merasa tertuduh, lebih lagi dari itu yakni tidak dapat menentukan jalan keselamatan. ${ }^{48}$

Allah sudah melakukan pembenaran, penebusan serta pendamaian di dalam Tuhan Yesus Kristus. Di dalam tindakan anugerah Allah ini mempertontonkan ketidakberdayaan manusia menolong dirinya sendiri. ${ }^{49}$ Ef.1:7 sebab di dalam Dia dan oleh darah-Nya kita beroleh penebusan yaitu pengampunan dosa. Ini suatu keyakinan dengan iman yang teguh bahwa Yesus menjamin melampaui pikiran dan perasaan manusia. Keselamatan yang Tuhan berikan tetap berhubung dengan pengampunan dosa yang telah diakui di hadapan Allah melalui penebusan oleh darah Yesus melayakkan dalam penerimaan. Keselamatan dalam Yesus bukanlah akan merasa positif tetapi suatu kebebasan atas semua dosa pelanggaran (Kolose 1:19-22). Upah dosa adalah maut (Roma 6:23), tetapi kasih karunia Allah manusia diselamatkan.

\section{Sikap Orang Percaya tentang Kekayaan Menurut Alkitab.}

\section{Kekayaan materi}

${ }^{47}$ GKI Pengharapan and Gereja Kristen Injili di Tanah Papua, “'DIBENARKAN KARENA IMAN (Roma 3 :

21 - 31)'”' (Papua, 2019), https://gkipengharapan.id/all-resource-list/dibenarkan-karena-iman-roma-3-21-31/.

${ }^{48}$ Ibid.

${ }^{49}$ Ibid.

Copyright $\bigcirc 2021$; Ritornera - Jurnal Teologi Pentakosta Indonesia $\mid 78$ 
Hidup berkelimpahan, adalah cara pandang bersifat materi dan legalistik. Mereka menganggap kekayaan adalah sebagai tanda bahwa Allah memberkati secara materi. Jadi materialis harus nyata di hidup orang yang percaya pada Allah. Menurut Alkitab, khususnya dalam Perjanjian Baru cenderung mengungkapkan banyak bahaya yang ditimbulkannya. Yesus sendiri dicobai iblis dengan kekayaan materi, “...semua itu akan kuberikan kepadaMu, jika Engkau sujud menyembah aku” (Mat.4:8-9). Kekayaan itu harta yang bersifat fana (Mat. 6:19); menjadi tipu daya sehingga orang percaya tidak berbuah (Mark.4:19); menghambat orang untuk masuk ke dalam Kerajaan Surga (Mat.19:23); penghibur yang salah (Luk. 6:24); focus pada hartanya dan melupakan Tuhan (Luk. 12:16-21); bersikap masa bodoh kepada yang memerlukan bantuan (Luk.16:19-26); menghambat orang itu maju mengikut Tuhan (Luk.18:22-23); menjadi jerat yang mencelakakan dan membinasakan (1 Tim.6:9). Memburu uang menyebabkan orang menyimpang dari iman (1 Tim.6:10). Peringatan agar jangan berharap pada kekayaan (1 Tim.6:17). Orang kaya bisa lenyap (Yak.1:10-11). Nasehat Yohanes agar menjauhkan diri dari yang berhubungan dengan harta dan kekayaan materi (1 Yoh.2:15-16).

Kekayaan yang Sesungguhnya.

Dalam Perjanjian Baru orang percaya diperingatkan untuk mengejar kekayaan yang sesungguhnya, seperti: harta yang kekal di surga, bukan materi (Mat.6:20; 19:21; Luk.12:23; Ibr.10:34). Kaya di hadapan Allah dengan berbuat baik yaitu memberi (Luk.12:21); kebaikan dan kebajikan (II Tim.6:18). Kaya dalam memberi sekalipun miskin harta (II Kor.8:2-3). Kaya dalam iman, perkataan, pengetahuan, kesungguhan membantu, dan dalam kasih (II Kor.8:7). Di dalam Kristus tersembunyi segala harta hikmat dan pengetahuan (Kol.2:2-3). Harta tentang kemuliaan yang melimpah berasal dari Allah pada Kristus (II Kor. 4:6-7). Kaya karena menjadi ahli waris 
Kerajaan Allah (Yak.2:5) dan harta yang indah dan dipercayakan, oleh Roh Kudus (II Tim.1:1314).

Tujuan memiliki harta.

Tuhan memerintahkan kepada orang percaya agar tidak mengumpulkan harta (Mat. 6:19-21) di dunia ini. Alasannya, karena kekayaan bersifat fana, kekayaan memerlukan penanganan secara khusus. Dalam mengikut Yesus, pemuda itu diperintahkan menjual hartanya dan membagikan kepada orang miskin (Luk. 18:22) namun pemuda itu tidak lulus seleksi ujian harta. Penyebabnya karena keterikatan di mana hartamu berada, disitu hatimu juga. Luk 12:33 jual hartamu, kepemilikan harta dalam maksud Tuhan bukan untuk keterikatan tetapi supaya kaya di hadapan Allah (Luk.12:22). Salah satu tujuan memiliki harta adalah terlibatnya harta dalam melayani Tuhan untuk maksud kekekalan. Perintah untuk Timotius adalah menasehati orang kaya agar suka memberi dan berbagi harta sebagai cara mengumpulkan harta di surga (tempat yang kekal) I Tim 6:17-19. Pemilik harta diperintahkan untuk mengubah kekayaan memiliki harta (materi) menjadi suatu harta di surga dengan cara membagikannya kepada mereka yang memerlukan. Baik harta sekalipun berupa uang ketika diberikan dalam maksud tujuan kekekalan maka konsekuensinya akan dipercayakan lebih banyak lagi. Bukan untuk ditimbun tetapi untuk disalurkan kembali.

Sikap yang benar terhadap kekayaan materi

Pertama, waspada terhadap katamakan: "Berjaga-jagalah dan waspadalah terhadap segala ketamakan, .....” (Lukas 12:15). Kata 'berjaga-jaga' dipakai kata 'horao' (bahasa Yunani) artinya melotot yaitu melihat sesuatu yang menarik perhatian. Kata 'waspada' dipakai kata 'phulasso' 
(Greek) artinya berjaga-jaga atau menjaga agar tidak lari, ${ }^{50}$ Arti dari kedua kata di atas menunjukkan bahwa ketamakan adalah sesuatu yang perlu mendapat perhatian dalam pengawasan karena sangat berbahaya. Maka tidak dapat dipungkiri bahwa ketamakan ini sudah masuk di segala lini kehidupan manusia seperti tingkat pribadi, masyarakat, kegiatan publik berskala besar atau kecil, juga gereja. Yang menjadi perhatian adalah apakah saya dan pelayanan yang ada sudah tercemari oleh ketamakan. Kedua, memiliki sikap mengelola kekayaan sesuai Alkitab. Matius 25:14-20 setiap individu akan bertanggungjawab terhadap apa yang diberikan Tuhan sebagai berkat tetapi itu merupakan milik Allah (Roma 11:36). Donald C. Stamp menyatakan bahwa seperti pandangan Yesus menunjuk kepada kekayaan menjadi suatu rintangan terhadap keselamatan dan kemuridan dalam mengikut Yesus. ${ }^{51}$

Ketiga, mengetahui bentuk-bentuk ketamakan itu diantaranya: I Tim.6:9-10 keinginan untuk menjadi kaya karena cinta uang. Keinginan menjadi kaya telah merasuk bukan saja kepada yang miskin tetapi juga kepada yang kaya. Sikap memburu uang membuat suatu penyembahan berhala, juga ada hubungan dengan roh-roh jahat. ${ }^{52}$ Dibalik semua berhala sudah ditunggangi oleh setan, oleh iblis. ${ }^{53}$ Kata 'jerat' seperti jerat untuk binatang buas atau burung dan dipakai sebagai gambaran seperti Ayub 5:13; Maz.9:17 - terjerat ke dalam tipu muslihatnya. Kesengajaan memakai atau memperalat ayat firman Tuhan yang 'dibungkus' - dieksploitasi sehingga kedengaran sangat rohani oleh jemaat, juga para pendeta dan pengajarnya. Tujuannya memperoleh uang yang banyak dari jemaat dan tanpa disadari telah masuk kepada jerat ketamakan. Sikap ini menunjukkan pengenalan akan Tuhan yang rendah dan tidak menghormati Tuhan. Gereja-gereja telah melangkah menyalahi cara yang bertanggungjawab seperti jargon-jargon Alkitab (kata-kata dari ayat firman): 'berilah,

\footnotetext{
${ }^{50}$ BibleWorks ceased operation as a provider of Bibleworks, "BibleWorks," 2018.

${ }^{51}$ Donald C Stamps, Alkitab Penuntun Hidup Berkelimpahan, 1st ed. (malang: Gandum Mas, 1994$), 1674$.

${ }^{52}$ Ibid.

53 Ibid., 435.
}

Copyright(C2021; Ritornera - Jurnal Teologi Pentakosta Indonesia |81 
maka kamu akan diberi' Luk. 6:38. 'yang menabur banyak akan menuai banyak' II Kor. 9:6. Persembahan perpuluhan menjadi ancaman kepada jemaat dengan kewajiban menandatangani surat ‘perjanjian dengan Tuhan’ sebagai ketaatan jemaat kepada gereja. ${ }^{54}$

Kikir (I Kor. 6:10) 'pleonektes' artinya 'menahan lebih' maksudnya apa yang ada padanya ditahan supaya tidak ada yang dikeluarkan. Seperti dalam perumpamaan Lazarus Lukas 16: 19-23 dimana orang kaya itu bersikap masa bodoh tidak ingin mengetahui keadaan orang lain. Christian Robirosa mencatat bahwa sekarang ini ada orang Kristen yang kaya dalam gereja Tuhan bersikap masa bodoh kepada orang miskin dan merasa sudah memberi untuk orang miskin melalui yayasan gereja. Dia menyatakan bahwa belum tentu gereja menyalurkan dengan tepat. Yang benar adalah seharusnya memperhatikan orang miskin dari hati yang mencintai, dengan kasih ilahi. ${ }^{55}$ Jadi, sifat kikir adalah menjaga agar uangnya tidak keluar dari genggamannya.

Hidup mewah dan boros seperti orang kaya itu memboroskan harta dengan bersenangsenang tanpa mempedulikan Lazarus sedikitpun (Lukas 12:18-19) menggambarkan sifat kikir dengan menimbun sedangkan ay.19 menggambarkan sifat boros. Memboroskan menunjukkan benda yang dimiliki berlebihan dan seakan tidak diperlukan lalu dengan sengaja dibiarkan tanpa diperhitungkan batasannya untuk kesenangan sendiri. Sikap orang Kristen yang benar adalah menyerahkannya kembali kepada Tuhan untuk dipergunakan dalam memberitakan Kerajaan Surga. ${ }^{56}$

Implementasi bagi gereja Tuhan dan orang percaya adalah menjauhi cara-cara tersebut agar tidak terjerat ke dalam utang serta harus bertobat dari sifat ketamakan. Pertama, Berkecukupan

\footnotetext{
${ }^{54}$ Avanzini., Untaian Nasehat Mengenai Kemakmuran.

55 Simanuhuruk, Teologi Kemakmuran. Apakah: Orang Benar Harus Kaya? Miskin Itu Karena Dosa?

56 Stamps, Alkitab Penuntun Hidup Berkelimpahan, 1674. 
dalam I Tim.6:8 'asal ada makanan dan pakaian, cukuplah'. Manusia memerlukan makanan dan pakaian yang merupakan kebutuhan hidup sehari-hari yang harus disediakan selalu yang sama seperti Yesus katakan di dalam Mat.6:25. 'Cukup' dapat berarti memiliki batasan, ada batas tidak melebihi atau berkelebihan dan bukan mewah. Filipi 4:11 'mencukupkan diri' dari kata 'autarkes' ${ }^{57}$ dari kata 'autos' artinya 'self' dan kata 'arkeo' artinya 'be contend, be sufficient' Jadi 'autarkes' artinya 'self contend, self sufficient' ialah merasa cukup. Ini menunjukkan dari dalam hati memiliki perasaan berkecukupan. Mat.6:11 'berikanlah kami pada hari ini makanan kami yang secukupnya', Ibr. 13:5 'janganlah kamu menjadi hamba uang dan cukupkanlah dirimu dengan apa yang ada padamu'. Kedua, terkoneksi dengan sumber. II Kor.9:8 'Dan Allah sanggup ... senantiasa berkecukupan di dalam ...' I Tim 6:6 'Memang ibadah itu kalau disertai dengan rasa cukup memberi keuntungan besar'. Jadi sumber hati yang merasa cukup adalah dari Allah dan dalam melaksanakan ibadah.

\section{KESIMPULAN}

Hidup berkelimpahan, adalah cara pandang bersifat materi dan legalistik. Mereka menganggap kekayaan adalah sebagai tanda bahwa Allah memberkati secara materi. Jadi materialis harus nyata di hidup orang yang percaya pada Allah, walaupun hal itu tidak menjadi penentu dalam kerohanian. Demikian dapat disimpulkan bahwa tinjauan teologis konsep hidup berkelimpahan dalam perspektif teologi kemakmuran. Pertama membawa jemaat dapat mengerti hakikat Hidup berkelimpahan dalam teologi kemakmuran dengan melihat latar belakang berdiri dan Ajaran Teologi Kemakmuran. Selanjutnya memahami secara konfrernhensif bahwa tinjauan Alkitab

${ }^{57}$ Rick Meyers, “E-Sword®” (Franklin, TN 37065 United States of America: Rick Meyers All Rights Reserved Worldwide, 2020). 
tentang beberapa ayat yang dipergunakan sebagai dasar untuk Hidup Berkelimpahan Sebagai Ajaran Teologi Kemakmuran menjadi apologet yang membawa paradigma baru. Dan yang terakhir

Tinjauan Alkitab tentang kelimpahan dalam perspektif Alkitab dan mengedukasi bagi Sikap orang percaya tentang kekayaan Menurut Alkitab. Sikap yang benar terhadap kekayaan materi untuk waspada terhadap ketamakan, sehingga dapat mengelola kekayaan dan mengetahui bentuk-bentuk ketamakan. Kelimpahan yang ditemukan adalah tentang kehidupan kekal dimana gereja harus tetap fokus kepada Kristus dan sebagai murid Yesus. Doktrin yang benar berlandaskan pada kebenaran Alkitab yang murni dengan penafsiran yang mumpuni dan berdasar pada standar yang kokoh.

\section{REFERENSI}

Alinurdin, David. “COVID-19 Dan Tumit Achilles Iman Kristen.” VERITAS Jurnal Teologi dan Pelayanan 19, no. 1 (2020): 1-9.

Autrey Jarry. Surat Kiriman Penjara. Malang: Gandum Mas, 1988.

Avanzini., John. Untaian Nasehat Mengenai Kemakmuran. Semarang: Literatur Gereja JKI-INJIL KERAJAAN, 1997.

Baharudin, Chairul, Ikhsan and Muhammad Abdi, and Nur. "Ancaman Krisis Ekonomi Global Dari Dampak Penyebaran Virus Corona (Covid-19).” AkMen Jurnal Ilmiah (2020).

Bakker, Jim. Teologi Kemakmuran Dan Kedatangan Tuhan. Jakarta: Metanoia, 2005.

Barnett, Jake. Harta Dan Hikmat. Bandung: Kalam Hidup, 1983.

Bibleworks, BibleWorks ceased operation as a provider of. "BibleWorks," 2018.

Chaniago, Amran Y S. “Kamus Lengkap Bahasa Indonesia.” Bandung: Pustaka Setia (2002). 
Darminta, S.J. Peziarahan Keluarga. Yoyakarta: Kanisius, 2006.

End, Van Den. “Tafsiran Alkitab Surat Roma.” Jakarta: BPK Gunung Mulia (1995).

Finilon, and I Ketut Enoh. "TINJAUAN TEOLOGIS TENTANG ARTI BERKAT DALAM KEHIDUPAN ORANG PERCAYA.” Jurnal Jaffray 10, no. 1 (2012): 148-173. https://ojs.sttjaffray.ac.id/JJV71/article/view/72/pdf_50.

Hadiwijono, Harun. Iman Kristen. Jakarta: BPK Gunung Mulia, 2007.

Indonesia, Lembaga Alkitab, ed. Alkitab Penuntun Hidup Berkelimpahan. Keenam. Malang: Gandum Mas, 2002.

Mondolu, Debby Christ, and and Obet Nego. "Covid-19: Wabah Alkitabiah, Relevankah?” SCRIPTA: Jurnal Teologi dan Pelayanan Kontekstual 9, no. 1 (2020): 32-51.

Morris, Leon. Teologi Perjanjian Baru. Pertama. Malang: Gandum Mas, 1996.

Mulyana, Yusep. “Peranan Ekonomi Pembangunan Pasca Covid 19.” PRISMAKOM Sekolah Tinggi Ilmu Ekonomi Yasa Anggana Garut 17, no. 1 (2020): 37-45.

Pengharapan, GKI, and Gereja Kristen Injili di Tanah Papua. “DIBENARKAN KARENA IMAN (Roma 3 : 21 - 31)."” Papua, 2019. https://gkipengharapan.id/all-resource-list/dibenarkankarena-iman-roma-3-21-31/.

Rick Meyers. "E-Sword®.” Franklin, TN 37065 United States of America: Rick Meyers All Rights Reserved Worldwide, 2020.

Ronda, Daniel. “Ulasan Buku: Bagaimana Aku Dapat Meminta Allah Untuk Kesembuhan Fisik?: 
Panduan Alkitabiah.” Jurnal Jaffray 13, no. 1 (2015).

https://ojs.sttjaffray.ac.id/JJV71/article/view/118.

Santo, Joseph Christ, and Yonatan Alex Arifianto. "Kajian Teologis 1 Petrus 5:7 Tentang Perlindungan Allah Terhadap Orang Percaya Di Tengah Pandemi Covid-19." Kharismata: Jurnal Teologi Pantekosta 4, no. 1 (2021): 1-15. https://www.ejournal.stajember.ac.id/index.php/kharismata/article/view/80/pdf.

Satya, Putu Agung Nara Indra Prima. ““‘Covid- 19 Dan Potensi Konflik Sosial.” Jurnal Ilmiah Hubungan Internasional 0, no. 0 (2020): 39-45.

Simanjuntak, A. Tafsiran Alkitab Masa Kini 3 Matius-Wahyu. 8th ed. Jakarta: Yayasan Komunikasih Bina Kasih/OMF, 1994.

Simanuhuruk, Sihol Christian Robirosa. Teologi Kemakmuran. Apakah: Orang Benar Harus Kaya? Miskin Itu Karena Dosa? Malang: Gandum Mas, 2009.

Stamps, Donald C. Alkitab Penuntun Hidup Berkelimpahan. 1st ed. malang: Gandum Mas, 1994.

Stanley, Charles. The Glorious Journal (Perjalanan Mulia). Batam Center: Interaksara, 2000.

Walangare, Stephen G. “Teologi Kemakmuran.” Kompasiana.Com.

Wijaya, Hengki. "Evaluasi Kritis Terhadap Teologi Sukses” (2012).

Zaluchu M.Th, Dr. Sonny Eli. Biblical Theology. 2nd ed. Semarang: Golden Gate, 2017.

Alkitab Hidup Berkelimpahan Life Application Study Bible. Malang: Gandum Mas, 2016.

Bible Work 7,0 0,12g, n.d. 
Ritornera - Jurnal Teologi Pentakosta Indonesia, Vol 1, No 2, August 2021

BibleWorks 7,0 0,12g, n.d. 